\title{
Women and Children as Vulnerable groups in India: Their Health and Human Rights
}

\author{
Miss Memi Rani Chintey, M.A (Political Science), Bentul Chintey (M.A, LL.B) \\ ${ }^{1,2}$ LL.M Final Year Centre for Juridical Studies, Dibrugarh University
}

\begin{abstract}
The objective of this paper is to find out the status, health and human rights of woman and children in India. Really, can we be considered women and children as vulnerable groups in India? There are certain groups of human beings which either by nature or because of deep-rooted custom is weak and vulnerable, such as, child, women, disabled persons, aged persons etc. India has given equal status to women under its Constitution under Article 14 which provides that "the State shall not deny to any person equality before the law or the equal protection of the laws within the territory of India". The Constitution of India provides under the Article 15 that every female citizen has a right to access to shops, public restaurants, hotels and places of public entertainment and no restriction can be imposed on female citizens with regard to the use of wells, tanks, bathing ghats, roads and places etc. However, in order to improve their status further, the Constitution provides under Article 15(3) state may make special provisions for women. Likewise, the constitution of India under Article 24 provides that no child below the age of fourteen years shall be employed in any factory or mine or engaged in any other hazardous employment is prohibited but Child labour is prevailing still in India. According to the international Labour Organisation estimated in 2000 some 211 million children between 5 to 14 years of age work in developing countries, with about half working full time.
\end{abstract}

Key words: vulnerable, child labour, exploitation, sex abuse, discrimination etc.

\section{Introduction}

In India there are certain groups of human beings which either by nature or because of deep-rooted custom is weak and vulnerable, such as, Women and Children disabled persons etc. However, they being human beings do possess human rights and fundamental freedoms. But their rights have been violated very frequently by the dominant section of the society. In India there are multiple socio-economic disadvantages that members of particular groups experience which limits their access to health and healthcare. The task of identifying the vulnerable groups is not an easy one. Besides there are multiple and complex factors of vulnerability with different layers and more often than once it cannot be analysed in isolation. The present document is based on some of the prominent factors on the basis of which individuals or members of groups are discriminated in India, i.e., structural factors, age, disability, mobility, stigma and discrimination that act as barriers to health and healthcare. The vulnerable groups that face discrimination include Women, children, Aged, Disabled. Sometimes each group faces multiple barriers due to their multiple identities. For example, in a patriarchal society, disabled women face double discrimination of being a women and being disabled.

\section{Methodology}

The present study is made on women and children's status and their health and human rights in India. It is noted that majority of the Indian Women and Children are exploited in our society. The information are collected from secondary source like, various books related to women and children, National Family Health Survey-2, 2000, journals, internet sources etc.

\section{Conditions of Indians Women and Children}

In India, members of gender, caste, class, and ethnic identity experience structural discrimination that impact their health and access to healthcare. Women face double discrimination being members of specific caste, class or ethnic group apart from experiencing gendered vulnerabilities. Women have low status as compared to men in Indian society. They have little control on the resources and on important decisions related to their lives. In India, early marriage and childbearing affects women's health adversely. About 28 per cent of girls in India get married below the legal age and experience pregnancy (Reproductive And Child Health District level Household Survey 2002-04, August 2006). These have serious repercussions on the health of women. Maternal mortality is very high in India. The average maternal mortality ratio at the national level is 540 deaths per 100,000 live births (National Family Health Survey-2, 2000). It varies between states and regions, i.e., rural-urban. The rural MMR (Maternal Mortality Rate) is 617 deaths of women age between 15-49 years per one lac live births as compared to 267 maternal deaths per one lac live births among the urban 
population (National Family Health Survey-2, 2000). In most cases the deaths occur from preventable causes. A large proportion of women is reported to have received no antenatal care. In India, institutional delivery is lowest among women from the lower economic class as against those from the higher class.

Women face violence and it has an impact on their health. During infancy and growing years a girl child faces different forms of violence like infanticide, neglect of nutrition needs, education and healthcare. As adults they face violence due to unwanted pregnancies, domestic violence, sexual abuse at the workplace and sexual violence including marital rape and honour killings. The experience of violence and its impact on health varies according to the women's caste, class and ethnic identity.

Children and the elderly population face different kind of vulnerability. Mortality and morbidity among children are caused and compounded by poverty, their sex and caste position in society. All these have consequences on their nutrition intake, access to healthcare, environment and education. These factors directly impacts food security, education of parents and their access to correct health information and access to health care facilities. Malnutrition and chronic hunger are the important causes of death among children from poor families. Diarrhoea, acute respiratory diseases, malaria and measles are some of the main causes of death among children, most of which are either preventable or treatable with low-cost interventions. Tetanus in new born remains a problem in at least five states: Uttar Pradesh, Madhya Pradesh, Rajasthan, West Bengal, and Assam (UNICEF, India). Poverty has a direct impact on the mortality and morbidity among children. Neo-natal mortality is about two times higher among people with low standard of living while Under-5 mortality among children from lower economic class is five times than that of households with high standard of living. 73.4 per cent of children have some form of anaemia (National Family Health Survey-2, 2000). In India, a girl child faces discrimination and differential access to nutritious food and gender based violence is evident from the falling sex ratio and the use of technologies to eliminate the girl child. Among children the health indicators vary between the different social groups. High mortality and morbidity is reported among children from Scheduled Castes, Scheduled Tribes and Other Backward Classes as compared to the general population.

Infant mortality is higher among the rural population (Rural-62, Urban 42 per one thousand live births in the last five years, National Family Health Survey 3). The vaccination coverage is very poor among children who live in rural India. Vaccination coverage among children between 12-23 months who have received the recommended vaccines is only 39 per cent in rural India as compared to 58 per cent in urban India (National Family Health Survey- 3, Fact sheets). In India, children's vulnerabilities and exposure to violations of their protection rights remain spread and multiple in nature. The manifestations of these violations are various, ranging from child labour, child trafficking, to commercial sexual exploitation and many other forms of violence and abuse. With an estimated 12.6 million children engaged in hazardous occupations (2001 Census), for instance, India has the largest number of child labourers under the age of 14 in the world. Child labour in the agriculture sector accounts for 80 per cent of child labour in India and 70 per cent of working children globally (Jaswal, Patro, et al., 2006). In, Sivakasi, an estimated 1, 25,000 children make the child labour force, comprising 30 per cent of the entire labour force. Those children working in the brick kilns, stone quarries, mines, and carpet and zari industry suffer from occupation related diseases. In India, however there is a huge gap in the industry-specific and exposure-specific epidemiological evidence. Most of the studies are small-scale and community-based studies. There is a large proportion of children in India who are living with HIV/AIDS. The most common sources of infection among children is the Mother-to-Child Transmission (MCTC), sexual abuse, blood transfusion, unsterilized syringes, including inject able drug use(NACO,2006). Among children, there are some groups like street children and children of sex workers who face additional forms of discrimination. A large number of children are reportedly trafficked to the neighbouring countries. Trafficking of children also continues to be a serious problem in India. The nature and scope of trafficking range from industrial and domestic labour, to forced early marriages and commercial sexual exploitation. Moreover, for children who have been trafficked and rescued, opportunities for rehabilitation remains scarce and reintegration process arduous. While systematic data and information on child protection issues are still not always available, evidence suggests that children in need of special protection belong to communities suffering disadvantage and social exclusion such as scheduled casts and tribes, and the poor (UNICEF, India).

\section{Scope And Limitations Of The Indian State Vis-A Vis Right To Health}

The Constitution of India and the laws do not accord health and healthcare as rights to the population in general. While civil and political rights are enshrined as fundamental rights that are justifiable, social and economic rights like health, education, livelihoods etc. exist as Directive Principles for the State and are hence not justifiable. There is however instances in which cases have been filed in the various High Courts of states and Supreme Court of India on the right to life, Article 21 of the Indian Constitution, or on the various directive principles to demand access to healthcare, especially in emergency situations.

International protection of human rights is only effective when they are made viable by national protection. National-level legislation, policies and enforcement mechanisms are the key factors in rights being 
organized for individuals and groups within a nation. National laws offer variable degrees of protection against human rights violation and enables national bodies to hear cases of denial and enforce the norms. At present there is a problem of justifiability of the Right to health in Indian Constitution since the same is not protected by national legislation. Though India has ratified the Treaty on the Economic Social and Cultural Right which covers Right to Health (Article 12), that cannot be effectively used to advocate for right to health in India. The Courts or petitioners can merely derive inspiration from the treaties on the cases on denial/violation on right to health but may not be able to use it effectively to deliver justice. The international treaties have only an evocative significance unless protected by national legislation. Absence of national legislation on right to health in India is the main reason why it cannot be realized.

Health and human rights advocacy in India needs to intensify the attempts towards transforming the critical principles of the Directive principles on health and work into independent rights through rigorous judicial activism, i.e., filing Public Interest Litigations, gathering testimonials for denial on right to health, etc. There needs to be a concerted move towards making a national legislation on right to health.

\section{Findings}

It is observed that women and child is really can be regards as vulnerable groups in India. They are discriminated by our society because of their nature of vulnerability in spite of existing so many acts for protection to them. Such as The Protection $\mathrm{f}$ Women from Domestic Violence Act,2005,The Prohibition of Child Marriage Act,2006,Dowry Prohibition Act,1961, Immoral Traffic Act,1956 with amendment in 2005 etc. And, likewise there have many acts for protection of children such as Child labour (Prohibition and Regulation) Act, 1986, Factories Act, 1948, Indian Mines Act, 1952 etc. But these acts are not being able to protect them.

\section{Suggestions}

* Identify disadvantaged/marginalized groups; their health status and needs in different situations

* Review the health information and services that are available to protect the health of the poor, vulnerable, or otherwise disadvantaged groups, including their quality, accessibility, affordability and acceptability.

* Collect disaggregated information on the health disparities among the marginalized groups. Identify the unmet need, particularly those resulting from adverse discrimination

*Identify barriers to the implementation of relevant laws, obligations and commitments; this could mean lack of political will; weak infrastructure or mechanisms for effective administration of policies and programmes; harmful traditional practices; cultural norms or policies imposed by and as a result of adverse reforms of the health sector to funding health services

* Increase public awareness on the right to health of the vulnerable groups and engage in community education and mobilization.

* Assess government compliance with specific obligations; whether government is meeting minimum essential level of health rights; whether there is systematic discrimination associated with the treatment of poor, vulnerable and otherwise disadvantaged groups.

* Undertake advocacy to facilitate change by identifying violations to right to health; familiarize yourself with the nature of the state obligations arising from the right to health and the common ways in which government violates them; document any identified violations and use it as a basis for monitoring and advocacy.

\section{Concluding Observation}

Thus, from the above discussion we may be concluded that though there are existing many laws and Acts for the protection of Women and Children but these are not be able to protect women and Child's rights and their fundamental freedom because of the mind set of our society. We have seen that the women and children are being exploited from the ancient time and at present $21^{\text {st }}$ century. We have seen in our day today life women are rape, murder, sexual harassment in their works place, public place etc. Likewise children also exploited due to their vulnerary nature. Thus, it is indicated that women and child are exploited in various aspects like economic, social etc. So, it is time to change our mind set view on women and child in our society and we should take care of them.

\section{References}

[1]. S.C. Tripathi and VibhaArora, Law relating to Women and Children, $14^{\text {th }}$ edition(Allahabad: Central Law Publicatiopns,2010)

[2]. Asha Bajpai,Child Rights in India, $2^{\text {nd }}$ edition(New Delhi: Oxford Indian Press,2011)

[3]. Adil-ul-Yasin and Archana Upadhyay, $1^{\text {st }}$ edition(New Delhi: Akansha Publication House, 2004)

[4]. H.O.Agarwal, $13^{\text {th }}$ edition(Allahabad: Central Law Publication,2006)

[5]. G.P. Tripathi, Law and Social Transformation (Allahabad: central Law Publication)

[6]. P. Ishara Bhat, Law and Social Transformation, $1^{\text {st }}$ edition (Lucknow: Eastern Book Company2009)

[7]. National Sample Survey Organisation (1998), Report on Morbidity and Treatment of Ailments, NSS-52ndRound, Report No 441, Government of India 
[8]. National Sample Survey Organisation (1998), Report on Maternal and Child Health Care in India, July1995-June-1996, NSS-52nd Round, Report No 445, Government of India

[9]. Convention on the Elimination of All Forms of Discrimination against Women (1979) http://www.ohchr.org/english/law/cedaw.htm

[10]. Declaration on the Elimination of Violence against Women (1993) http://www.unhchr.ch/html/menu3/b/21.htm

[11]. General Recommendation 14 of the Committee on the Elimination of Discrimination against Women (CEDAW) on female circumcision (1990) http://www.un.org/womenwatch/daw/cedaw/recommendations/recomm.htm

[12]. General Recommendation 19 of CEDAW on violence against women (1992) http://www.un.org/womenwatch/daw/cedaw/recommendations/recomm.htm

[13]. General Recommendation 24 on women and health (1999) http://www.un.org/womenwatch/daw/cedaw/recommendations/recomm.htmConvention on the Rights of the Child (1989) http://www.unhchr.ch/html/menu3/b/k2crc.htm

[14]. ILO Convention No 138 (Minimum Age for Admission to Employment, 1973)

[15]. www.ilocarib.org.tt/childlabour/c138.htm

[16]. ILO Convention No 182 (Worst Forms of Child Labour Convention, 1999) - http://www.ilocarib.org.tt/childlabour/c182.htm

[17]. United Nations Standard Minimum Rules for the Administration of Juvenile Justice (1985) http://www.unhchr.ch/html/menu3/b/h_comp48.htm

[18]. United Nations Rules for the Protection of the Juveniles Deprived of their Liberty (1990) http://www.unhchr.ch/html/menu3/b/h_comp37.htm

[19]. Declaration of the Rights of the Child (1959) -http://www.unhchr.ch/html/menu3/b/25.htm

[20]. General Comment 4 on adolescent health and development in the context of the Convention on the Rights of the Child (2003) http://www.unhchr.ch/tbs/doc.nsf/(symbol)/CRC.GC.2003.4.En?openDocument 